\title{
HISTOFISIOLOGI RETINA
}

\author{
Sunny Wangko \\ Bagian Anatomi-Histologi Fakultas Kedokteran Universitas Sam Ratulangi Manado \\ Email: sunnywangko@yahoo.com
}

Bola mata orang dewasa berdiameter sekitar 2,5 cm. Dari seluruh permukaan bola mata, hanya $1 / 6$ bagian anterior yang tampak sedangkan 5/6 bagian posterior terletak dan terlindung di dalam ruang orbita. Secara histologik, dinding bola mata tersusun oleh 3 lapisan yaitu tunika fibrosa, tunika vaskulosa (uvea), dan tunika nervosa (retina). Retina merupakan tempat reseptor visual dengan tiga lapisan utama neuron retina yang dipisahkan oleh dua zona dimana terjadi sinaps, yaitu lapisan sinaps luar dan dalam. Ketiga lapisan ini (searah dengan input visualnya) ialah: lapisan sel fotoreseptor, lapisan sel bipolar, dan lapisan sel ganglion. Juga terdapat sel horisontal dan sel amakrin; keduanya membentuk jalur lateral untuk mengatur sinyal yang dihantarkan sepanjang jalur sel fotoreseptor ke sel bipolar dan ke sel ganglion.

\section{LAPISAN-LAPISAN BOLA MATA}

\section{Tunika fibrosa}

Tunika fibrosa merupakan lapisan terluar bola mata, terdiri dari kornea di bagian anterior, dan sklera dibagian posterior (Gambar 1).

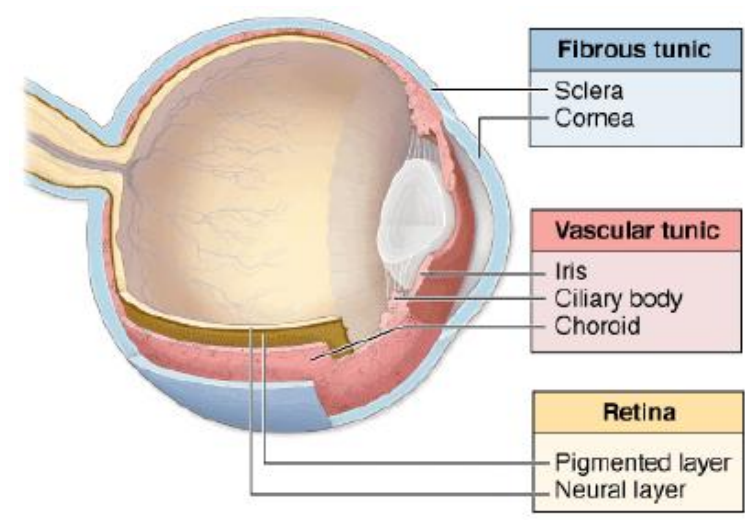

Gambar 1. Lapisan-lapisan bola mata. Potongan sagital bola mata memperlihatkan tiga lapisan utama (tunika) serta lensa sebagai pintu depan tunika vaskulosa dan retina. Sumber: Mescher AL, 2010.

Kornea merupakan struktur avaskular yang bening menutupi iris, dan berbentuk lengkung yang membantu mengfokuskan cahaya. Permukaan luarnya dilapisi oleh epitel berlapis gepeng dengan permukaan rata, yang berkesinambungan dengan epitel konjungtiva bulbi. Kornea sangat kaya dengan persarafan.

Sklera (bagian putih mata) merupakan lapisan jaringan ikat padat yang menutupi seluruh permukaan bola mata, kecuali kornea. Sklera memberikan bentuk bola mata, menjadikannya kaku, dan melindungi dalaman mata. Pada permukaan posteriornya terdapat foramen optikum, yang mengelilingi nervus optikus (nervus kranialis II). Pada tautan antara sklera dan kornea terdapat sinus venosus sklera yaitu kanalis Schlemm.

\section{Tunika vaskulosa}

Tunika vaskulosa merupakan lapisan tengah bola mata, dan terdiri dari tiga bagian, dari posterior ke anterior: koroid, korpus siliaris, dan iris.

Koroid merupakan bagian posterior tunika vaskulosa, kaya dengan vaskularisasi, dan menutupi sebagian besar permukaan dalam sklera. Lapisan ini memasok 
bahan nutrisi ke permukaan posterior retina. Melanosit menghasilkan pigmen melanin dan memberikan warna coklathitam pada koroid.

Ke arah anterior, koroid beralih menjadi korpus siliaris yang merupakan bagian tunika vaskulosa yang paling tebal. Korpus siliaris meluas dari ora serata (margo anterior retina) ke daerah tepat di posterior tautan sklerokorneal. Pada korpus siliaris terdapat prosesus siliaris dan muskulus siliaris. Prosesus siliaris merupakan tonjolan/lipatan pada permukaan dalam korpus siliaris dimana sel-sel epitelnya menyekresi humor akueus. Muskulus siliaris merupakan otot polos berbentuk pita sirkular yang mengubah bentuk lensa untuk penglihatan jauh atau dekat.

Iris ialah bagian berwarna bola mata yang berbentuk donat gepeng. Iris terletak di antara kornea dan lensa, dilekatkan pada bagian luarnya ke prosesus siliaris. Iris terdiri dari serat otot polos sirkular dan radial, dan lubang di tengahnya disebut pupil. Fungsi iris untuk mengatur jumlah cahaya yang masuk ke bagian posterior bola mata melalui pupil. Pada rangsangan cahaya terang, serat saraf parasimpatis merangsang otot polos sirkular (muskulus sfingter/konstriktor pupilae) untuk berkontraksi dan menyempitkan ukuran pupil (konstriksi). Pada cahaya redup, serat saraf simpatis merangsang otot polos radial (muskulus dilatator pupilae) untuk berkontraksi dan memperbesar ukuran pupil (dilatasi). Respons-respons ini bersifat refleks viseral.

Otot-otot intrinsik mata yaitu muskuli siliaris, sfingter pupilae, dan dilatator pupilae; ketiga-tiganya berasal dari ektoderm.

\section{Tunika nervosa (retina)}

Lapisan bola mata yang paling dalam yaitu retina, melapisi 3/4 posterior bola mata dan merupakan awal jalur penglihatan. Dengan oftalmoskop, melalui pupil dapat terlihat bayangan retina yang diperbesar serta pembuluh darah yang berjalan pada permukaan anteriornya. Retina merupakan satu-satunya tempat di dalam tubuh dimana pembuluh darah dapat diamati secara langsung dan dievaluasi kelainan patologiknya, antara lain pada hipertensi dan diabetes mellitus. Selain pembuluh darah, terdapat beberapa struktur lain yang dapat diamati; diskus optikus (blind spot, bintik buta), tempat keluarnya nervus optikus dari bola mata, serta arteri dan vena sentralis retina yang berjalan bersama nervus optikus.

Retina terdiri dari epitel pigmen (bagian non-visual) dan bagian neural (bagian visual). Epitel pigmen merupakan selapis sel epitel yang mengandung pigmen melanin, terletak di antara koroid dan bagian neural retina. Melanin pada koroid dan epitel pigmen menyerap cahaya sehingga dapat mencegah pantulan dan penyebaran cahaya di dalam bola mata. Dengan demikian, bayangan yang terlihat jelas. Pada individu albino, kekurangan pigmen melanin terdapat di seluruh bagian tubuh, termasuk mata.

Retina terdiri atas 10 lapisan, dari luar ke dalam: epitel pigmen, lapisan batang dan kerucut, membran limitans eksterna, lapisan inti luar, lepisan pleksiform luar, lapisan inti dalam, lappisan pleksiform dalam, lapisan sel ganglion, lapisan serat saraf, dan membran limitans interna (Gambar 2).

Bagian neural retina merupakan hasil penonjolan otak. Bagian ini memroses data sebelum dihantarkan oleh impuls saraf ke hipotalamus, kemudian ke korteks visual primer. Terdapat tiga lapisan utama neuron retina yang dipisahkan oleh dua zona dimana terjadi sinaps, yaitu lapisan sinaps luar dan dalam. Ketiga lapisan ini (searah dengan input visualnya) ialah: lapisan-lapisan sel fotoreseptor, sel bipolar, dan sel ganglion. Juga terdapat sel horisontal dan sel amakrin yang membentuk jalur lateral untuk mengatur sinyal yang dihantarkan sepanjang jalur sel fotoreseptor ke sel bipolar dan ke sel ganglion.

Fotoreseptor dikhususkan untuk 
transduksi gelombang cahaya menjadi potensial reseptor. Terdapat dua jenis fotoreseptor yaitu sel batang (rod, bacili) dan kerucut (cone, coni). Pemberian nama berdasarkan bentuk segmen luar sel fotoreseptor yang terletak di antara tonjolan-tonjolan sel epitel pigmen yang berbentuk jari. Masing-masing retina mempunyai 6 juta sel kerucut dan 120 juta sel batang. Sel batang berfungsi untuk penglihatan hitam putih pada cahaya remang-remang; juga untuk membedakan bayangan gelap atau terang dan melihat bentuk dan pergerakan. Sel kerucut berfungsi untuk penglihatan warna dan ketepatan penglihatan pada cahaya terang. Sebagai contoh: pada cahaya bulan kita tidak dapat membedakan warna karena hanya sel batang yang bekerja.

Sel kerucut umumnya terpusat pada fovea sentralis yaitu lekukan kecil di tengah makula lutea yang terletak tepat pada sumbu penglihatan. Fovea sentralis merupakan daerah dengan ketajaman penglihatan tertinggi karena padatnya sel kerucut pada daerah tersebut. Sel batang tidak ditemukan pada fovea dan makula dan jumlahnya meningkat kearah tepi retina. Oleh karena itu kita bisa melihat cukup baik pada malam hari kecuali bila melihat langsung ke obyek tertentu.

Dari sel-sel fotoreseptor informasi diteruskan ke sel bipolar melalui lapisan sinapsis luar (lapisan pleksiform luar ) dan kemudian ke sel ganglion melalui lapisan sinapsis dalam (lapisan pleksiform dalam). Akson sel ganglion meluas ke posterior, ke diskus optikus, dan keluar dari bola mata sebagai nervus optikus. Pada daerah ini tidak terdapat sel kerucut maupun batang; kita tidak dapat melihat bayangan pada bintik buta. Dalam keadaan normal, adanya bintik buta ini tidak disadari.

\section{SEL FOTORESEPTOR DAN FOTO- PIGMEN}

Sel fotoreseptor dibedakan berdasarkan bentuk segmen luar, yaitu ujung distalnya yang berdekatan dengan epitel pigmen. Transduksi cahaya menjadi sinyal listrik terjadi pada segmen luar.

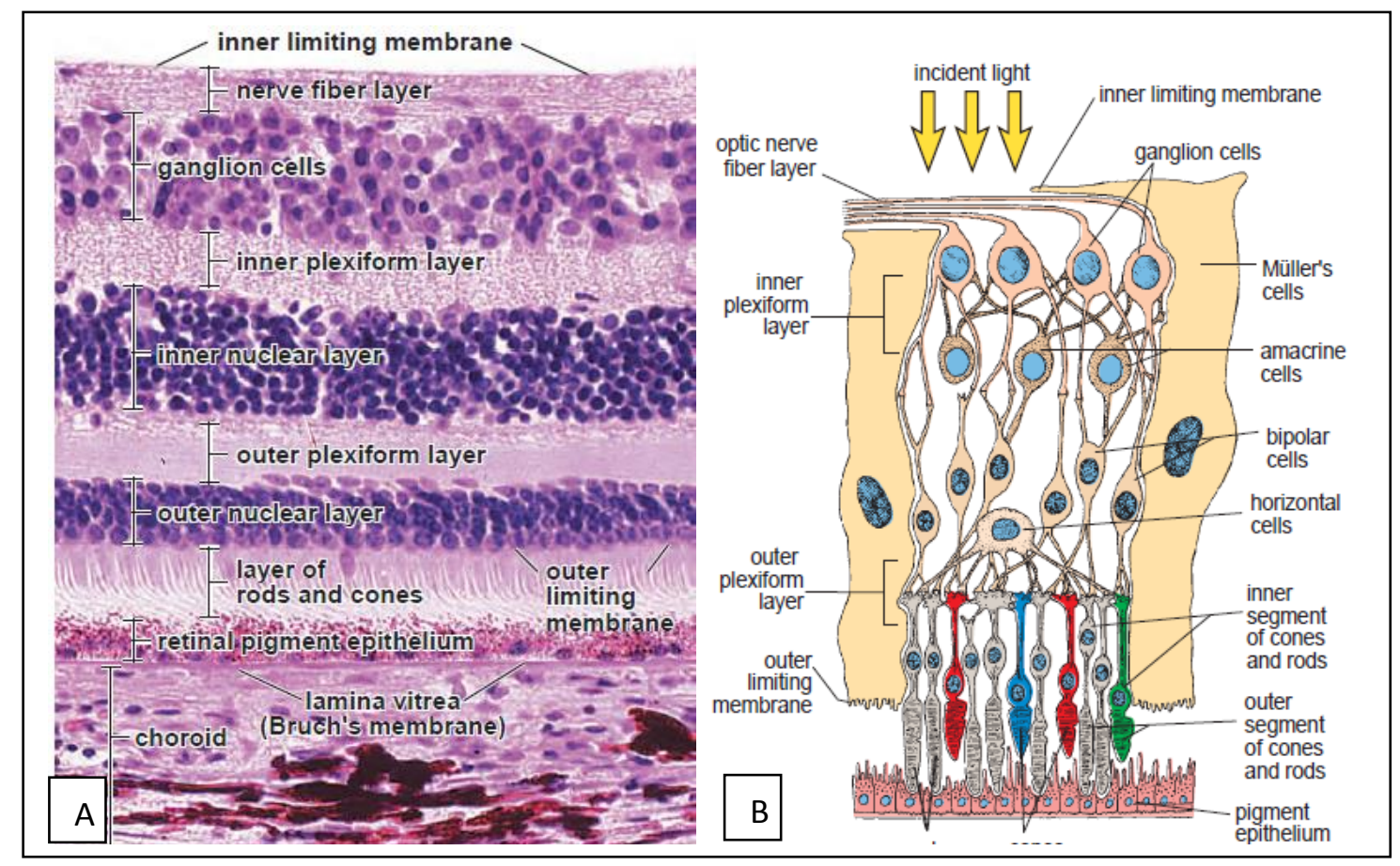

Gambar 2. A, Fotomikrograf retina manusia. B, Gambar skematik lapisan-lapisan retina. Sumber: Ross MH, Pawlina W, 2011. 
Segmen dalam mengandung inti sel, kompleks Golgi, dan banyak mitokondria. Ujung proksimal sel fotoreseptor meluas membentuk terminal sinaptik.

Tahap pertama transduksi visual ialah absorpsi cahaya oleh fotopigmen (visual pigment). Fotopigmen adalah protein berwarna pada membran segmen luar yang mengalami perubahan struktural oleh absorpsi cahaya dan mengawali peristiwa yang menghasilkan potensial reseptor. Semua fotopigmen visual terdiri dari dua bagian: glikoprotein, disebut opsin, dan derivat vitamin $\mathrm{A}$, disebut retinal (retinald). Opsin sel batang disebut rod opsin (rhodopsin) sedangkan pada sel kerucut disebut cone opsin. Cone opsin bersama dengan retinald disebut iodopsin.

\section{Aplikasi klinis}

\section{Buta senja}

Buta senja (night blindness, nyctalopia) adalah ketidak sanggupan untuk melihat dengan baik pada cahaya remangremang. Umumnya, hal ini disebabkan oleh defisiensi vitamin A jangka panjang yang berakibat ketidaksanggupan menyintesis rhodopsin dalam jumlah yang cukup.

Fotopigmen merupakan protein integral dalam membran plasma segmen luar, tersusun berlipat-lipat. Pada sel batang, lipatan-lipatan ini mencuat dari membran plasma membentuk diskus. Setiap segmen luar sel batang mengandung sekitar 1000 diskus, tersusun seperti uang logam. Segmen luar fotoreseptor diperbaharui dengan cepat. Untuk sel batang 1-3 diskus ditambahkan pada dasar segmen luar setiap jam. Secara serentak, diskus lama dikeluarkan melalui puncak segmen luar kemudian difagositosis oleh epitel pigmen.

Retinal merupakan bagian penyerap cahaya dari fotopigmen visual. Pada retina manusia terdapat empat jenis opsin, satu jenis rod opsin dan tiga jenis cone opsin. Terdapat perbedaan dalam rangkaian asam amino sehingga sel batang dan kerucut dapat mengabsorsi warna-warna yang berbeda dari cahaya yang masuk. Rod opsin terutama mengabsorpsi warna biru sampai hijau, sedangkan cone opsin mengabsorpsi terutama biru, hijau dan kuning sampai merah.

Retinal terdapat dalam dua bentuk. Dalam suasana gelap retinal berbentuk membengkok, cis-retinal, yang terletak cekat pada opsin. Bila mengabsorpsi cahaya cis-retinal melurus, membentuk trans-retinal. Perubahan ini disebut isomerisasi, tahap awal transduksi. Setelah proses isomerisasi beberapa bahan yang tak stabil dibentuk dan menghilang lagi. Dalam sekitar 1 menit trans-retinal lengkap terpisah dari opsin. Produk akhir tampak tidak berwarna, proses pemutihan (bleaching). Dalam suasana gelap, enzim retinal isomerase dapat mengubah kembali trans menjadi cis-retinal, berikatan dengan opsin dan membentuk kembali fotopigmen yang fungsional, proses regenerasi.

Epitel pigmen menyimpan vitamin A dalam jumlah besar dan berperan dalam proses regenerasi sel batang. Dengan demikian regenerasi rod opsin akan sangat terganggu bila retina terlepas dari epitel pigmen. Fotopigmen sel kerucut beregenerasi jauh lebih cepat dari pada sel batang dan kurang tergantung pada epitel pigmen. Setelah pemutihan lengkap, diperlukan 5 menit untuk regenerasi $1 / 2$ rod opsin sedangkan untuk $1 / 2$ cone opsin hanya diperlukan $1 \frac{1}{2}$ menit. Regenerasi penuh untuk rod opsin dicapai dalam 30-40 menit.

\section{Buta warna}

Buta warna (color blindness) adalah ketidaksanggupan untuk mengenal warnawarna tertentu diakibatkan oleh tidak adanya atau kekurangan salah satu fotopigmen sel kerucut. Jenis yang umum ialah buta warna merah-hijau dimana salah satu fotopigmen, untuk merah atau hijau, tidak ada. Individu melihat kedua warna tersebut sama, hijau atau merah, tergantung pada fotopigmen yang ada. Buta warna merupakan keadaan yang diturunkan melalui kromosom $\mathrm{X}$, sehingga terutama ditemukan pada laki-laki. 


\section{ADAPTASI TERANG DAN GELAP}

Bila kita berpindah dari tempat yang gelap ke yang terang maka sistem visual akan beradaptasi dengan menurunkan kepekaannya selama beberapa detik (adaptasi terang). Sebaliknya, bila kita berpindah dari tempat yang terang ke tempat yang gelap maka kepekaan visual akan meningkat perlahan selama beberapa menit (adaptasi gelap).

Dengan meningkatnya penerangan, maka lebih banyak fotopigmen mengalami pemutihan sehingga lebih banyak cahaya yang dibutuhkan untuk merangsang fotopigmen sisa yang belum mengalami pemutihan. Pada saat yang sama terjadi pemutihan dan regenerasi. Regenerasi rod opsin terjadi lebih lambat dimana pada cahaya siang kecepatan pemutihan sama dengan kecepatan regenerasi. Oleh karena itu sel batang kurang berperan pada penglihatan terang. Regenerasi pigmen sel kerucut terjadi cepat, sehingga sebagian bentuk cis selalu tetap ada, bahkan pada cahaya yang sangat terang.

Bila tingkat penerangan menurun secara cepat, mula-mula kepekaan meningkat sangat cepat kemudian melambat. Pada keadaan gelap, regenerasi penuh fotopigmen sel kerucut terjadi dalam 8 menit pertama adaptasi gelap. Dalam selang waktu ini kilatan cahaya terlihat berwarna. Secara lambat, rod opsin beregenerasi dan kepekaan visual meningkat sampai dapat mendeteksi setitik berkas cahaya, kemudian lebih banyak lagi cahaya remang yang dapat dideteksi, dan tampak sebagai putih kelabu. Pada cahaya remang, penglihatan tampak kelabu karena hanya sel batang yang berfungsi.

\section{Potensial reseptor}

Dalam keadaan gelap, $\mathrm{Na}^{+}$masuk ke dalam segmen luar fotoreseptor melalui saluran $\mathrm{Na}^{+}$yang dipertahankan terbuka oleh siklik cyclic guanosine monophosphate (GMP). Aliran ini disebut arus gelap (dark current), yang memicu secara kontinu pelepasan neurotransmiter dari terminal sinaptik. Neurotransmiter pada sel batang, dan mungkin juga pada sel kerucut, yaitu asam glutamat, menghambat (hiperpolarisasi) sel bipolar yang bersinaps dengan sel batang.

Bila cahaya mengenai retina, cisretinal mengalami isomerisasi, saluran $\mathrm{Na}^{+}$ tertutup. Arus masuk $\mathrm{Na}^{+}$berkurang, bagian dalam sel batang menjadi lebih negatif (hiperpolarisasi) dan pelepasan glutamat berkurang. Cahaya redup menyebabkan hiperpolarisasi ringan dan sementara, yang secara parsial menghentikan pelepasan glutamat. Cahaya yang lebih terang mengakibatkan hiperpolarisasi yang lebih kuat dan lama, yang secara lebih lengkap menghambat pelepasan neurotransmiter. Jadi, cahaya merangsang sel bipolar yang bersinaps dengan sel batang melalui penghentian inhibisi neurotransmiter.

Terdapat dua enzim yang menutup dan membuka kembali segmen luar. Pada keadaan terang, enzym transdusin mengaktifkan enzim fosfodiesterase (PDE), yang memecahkan siklik GMP. Hal ini akan mengakibatkan tertutupnya saluran $\mathrm{Na}^{+}$ yang menghasilkan hiperpolarisasi sel batang dan mengurangi pelepasan glutamat. Dalam keadaan gelap transdusin berbentuk tidak aktif, dan siklik GMP mempertahankan saluran $\mathrm{Na}^{+}$terbuka. Enzim recoverin mengaktifkan guanilat siklase yaitu enzim yang mengstimulasi siklik GMP. Dengan meningkatnya kadar siklik GMP, saluran $\mathrm{Na}^{+}$akan tetap terbuka dan aliran masuk $\mathrm{Na}^{+}$akan meningkatkan pelepasan glutamat.

\section{JALUR VISUAL}

Pemrosesan input visual terjadi di retina pada sinaps antara berbagai jenis sel. Akson sel ganglion retina menghasilkan output dari retina ke otak, dan keluar sebagai nervus optikus (n II).

\section{Pemrosesan input visual pada retina}

Didalam retina, bayangan input visual diperbesar sedangkan yang lainnya dihilangkan. Input dari beberapa sel dapat terkumpul (konvergen) pada neuron pasca 
sinaps yang jumlahnya lebih kurang atau menyebar (divergen) ke jumlah yang lebih besar. Umumnya, yang mendominasi ialah input yang terkumpul karena hanya terdapat 1 juta sel ganglion yang melayani 126 juta sel fotoreseptor.

Bila terjadi potensial reseptor pada sel batang dan kerucut, maka akan menyebar melalui segmen dalam sel-sel tersebut ke terminal sinaps. Neurotransmiter yang dilepaskan oleh sel batang dan kerucut menginduksi potensial lokal secara bertahap pada sel bipolar dan sel horizontal. 6600 sel batang bersinaps dengan satu sel bipolar pada lapisan sinaps luar sedangkan sel kerucut umumnya bersinaps dengan satu sel bipolar saja. Terkumpulnya banyak sel batang ke satu sel bipolar menyebabkan visi sel batang lebih peka tetapi lebih kurang cepat dari pada sel kerucut. Stimulasi cahaya pada sel batang mengeksitasikan sel bipolarnya. Sebaliknya, sel bipolar yang bersinaps dengan sel kerucut bisa diaktifkan atau diinhibisi oleh cahaya.

Sel horisontal menghantarkan sinyal inhibisi ke sel bipolar di bagian lateral sel batang dan kerucut yang terangsang. Inhibisi lateral ini meningkatkan kontras pada penglihatan antara daerah retina yang distimulasi kuat dan daerah sebelahnya yang kurang distimulasi. Sel horisontal juga berperan dalam diferensiasi berbagai jenis warna. Sel amakrin yang dieksitasi oleh sel bipolar, akan bersinaps dengan sel ganglion. Bila sel bipolar atau amakrin menghantarkan sinyal eksitasi ke sel ganglion, maka sel ganglion berdepolarisasi dan menginisiasi impuls saraf.

\section{DAFTAR PUSTAKA}

1. Gartner LP, Hiatt JL. Color Textbook of Histology (Third Edition). Philadelphia: Saunders Elsevier; 2007.

2. Ham AW, Leeson TS. Histology (Fourth Edition). Philadelphia: JB Lippincott Co; 1961.

3. Leeson RC, Leeson TS, Paparo AA. Textbook of Histology (Fifth Edition). Philadelphia: WB Saunders Co, 1985.

4. Marieb EN. Human Anatomy and Physiology (Second Edition). Redwood City: The Benjamin/Cummings Publishing Co; 1992.

5. Mescher AL. Junqueira's Basic Histology Text \& Atlas (Twelfth Edition). New York: McGrawHill Medical; 2010.

6. Ravaiola E. Bloom \& Fawcett. A Textbook of Histology (Twelfth Edition). New York: Chapman \& Hall; 1994.

7. Ross MH, Pawlina W. Histology a Text and Atlas (Sixth Edition). Philadelphia: Wolters Kluwer Lippincott Williams \& Wilkins; 2011.

8. Tortora GJ, Grabowski SR. Principles of Anatomy and Physiology (Ninth Edition). New York: Harper Collins; 2000. 